\title{
Homeowner Preferences for Wildfire Risk Mitigation in the Alaskan Wildland Urban Interface
}

\author{
Allen Molina ${ }^{1, *(\mathbb{D}}$, Joseph Little ${ }^{2}$, Stacy Drury ${ }^{3}$ and Randi Jandt ${ }^{4}(\mathbb{D}$ \\ 1 School of Management, University of Alaska Fairbanks, 201 Bunnell Building, Fairbanks, AK 99705, USA \\ 2 W. A. Franke College of Business, Northern Arizona University, 101 E. McConnell Drive, \\ Flagstaff, AZ 86011, USA; Joseph.Little@nau.edu \\ 3 Pacific Southwest Research Station, USDA Forest Service 1731 Research Park Drive, Davis, CA 95618, USA; \\ stacy.a.drury@usda.gov \\ 4 International Arctic Research Center, University of Alaska Fairbanks, 2160 N. Koyukuk Drive, \\ Fairbanks, AK 99705, USA; rjandt@alaska.edu \\ * Correspondence: acmolina@alaska.edu
}

Citation: Molina, A.; Little, J.; Drury, S.; Jandt, R. Homeowner Preferences for Wildfire Risk Mitigation in the Alaskan Wildland Urban Interface. Sustainability 2021, 13, 11754. https:// doi.org/10.3390/su132111754

Academic Editors: Robert P. Berrens and Benjamin A. Jones

Received: 27 August 2021

Accepted: 18 October 2021

Published: 25 October 2021

Publisher's Note: MDPI stays neutral with regard to jurisdictional claims in published maps and institutional affiliations.

Copyright: (c) 2021 by the authors. Licensee MDPI, Basel, Switzerland. This article is an open access article distributed under the terms and conditions of the Creative Commons Attribution (CC BY) license (https:// creativecommons.org/licenses/by/ $4.0 /)$.

\begin{abstract}
Wildfire has become a larger threat to human life and property with the proliferation of homes into the wildland urban interface and warming climate. In this study we explored Alaskan homeowner preferences for wildfire risk mitigation in the wildland urban interface using discrete choice experiments to better understand the drivers of their risk mitigation actions. Estimates of willingness-to-pay for private mitigation actions are increased with wildfire risk reduction for all respondents. Willingness-to-pay for private mitigation is also positively associated with the presence of thinned fuel treatments on nearby public lands, but is estimated to decrease if cleared fuel treatments are present on public lands. Our study concludes that homeowners minimize wildfire risk while maintaining neighborhood amenity values. Additionally, findings suggest that there is an optimal amount of neighborhood participation to motivate individual risk mitigation actions, as well as having a say in the mitigation actions on public lands.
\end{abstract}

Keywords: choice experiment; non-market valuation; willingness to pay; survey; wildfire economics; hazardous fuels; subjective risk

\section{Introduction}

The Wildland Urban Interface (WUI) is where communities meet and intersperse with undeveloped wildlands. WUI areas are particularly vulnerable to wildfire, yet development in these zones is the fastest growing land use type in the contiguous U.S., up 1/3 from 1990 to 2010 [1]. Alaska's WUI share similar vulnerabilities to WUI areas in general [2]. Even though Alaskan boreal forest fuel buildup from suppression isn't as impactful as other areas [3], excess fuels in the WUI can make fires burn hotter and more severely. Anthropogenic climate change is also altering wildfire risk in the Alaskan WUI. Climate change has already begun to intensify wildfire activity in portions of the western United States and is anticipated to continue increasing activity in the coming years [4]. Alaska's forests are anticipated to burn more severely, be susceptible to more fire danger days, and smoke from wildfires is expected to pose an increased risk to Alaskans under potential future climate scenarios [5-8]. The Intergovernmental Panel on Climate Change (IPCC) identifies how climate change affects wildfire regimes including increased risk and severity [9]. Climate-related wildfire regime changes including longer fire seasons will also compound challenges with excess fuel accumulation in WUI locations, posing a larger threat to life and property [10]. Alaskans will not only be faced with increasing costs associated with climate altered fire regimes, as virtually all projected climate scenarios will increase wildfire suppression costs [11], but will be under more pressure to reduce their home ignition risks by reducing fuels on their property. This study aims to enhance our 
understanding of factors which shape homeowner preferences for fuel reduction in the Alaskan WUI.

There have been a number of studies examining the effects of wildfire on residents and the economic damage at the individual and community levels [12-14]. Wildfires occurring in wildlands near WUI neighborhoods give residents little opportunity to react. People in these communities have little control over wildfire spread beyond their property boundaries. Even so, homeowners can still make a priori decisions to reduce their individual risk that can affect wildfire risk and house ignition probabilities for their entire neighborhood. Effort put into pre-suppression activities can lessen fire impacts, while also lowering overall suppression costs [15]. Because risk mitigation actions are an essential element to suppressing wildfire in WUI communities, programs such as Firewise [16] help defend against wildfire by educating and building support networks. Because the success of wildfire suppression can depend closely on pre-suppression activities of individual homeowners, we seek to understand the factors which drive homeowners to invest in risk mitigation actions on their property. We built a discrete choice experiment to estimate Alaskan homeowners' Willingness-To-Pay (WTP) for wildfire risk reduction on their own property in the presence of a number of factors including the level of neighborhood involvement, the level of risk reduction to their property as well as that of their neighbors, and the presence or absence of fuel treatments on nearby public lands.

A distinct set of complexities necessitate that the state of Alaska manage wildfire in a unique fashion. Both the size of the state and a small, but clustered population facilitate unique fire management strategies. For example, interagency planning prescribes allowing wildfires to passively burn if there are no identified infrastructure or resource values at risk from fire to protect [17]. A significant portion of the state's population live in small scattered, usually roadless, communities surrounded by forest or tundra. Private property in these locations can be at substantially higher risk than others in more populated areas due to proximity to hazardous wild vegetation, lack of local fire departments, and their remote locations. Mitigation actions taken on private lands can offer benefits to individual homeowners as well as entire WUI neighborhoods in the form of communal risk reduction. If state and federal agencies want to incentivize homeowners to minimize fuels on their property, they must recognize how homeowners value this wildfire risk reduction. Specifically, they need to estimate the value homeowners put on their own risk mitigation actions, the level of combined neighborhood mitigation activity, and the amount of land management agency involvement. These values could support future discussion of wildfire mitigation programs which incentivize individual homeowner action.

The number and costs of wildfires affecting human life and property in Alaska is burdensome. For the period between 2007-2020, there were approximately 250 wildfires that were larger than 50 acres in fire management areas identified as critical and full protection zones (for a full definition of the zones, please see the 2019 Alaska Statewide Master Agreement [17]). These fires destroyed approximately 305 structures. Most of this structural damage occurred during four fires: The Caribou Hills Fire (2007), the Hastings Fire (2011), the Sockeye Fire (2015), and the McKinley Fire (2019) [18]. In 2015, there were over 5.1 million acres burned statewide. The fires caused widespread smoke and poor visibility for many Alaskan residents. Suppression costs have reached new highs in recent decades. The Funny River Fire in 2014 cost approximately $\$ 11.5$ million dollars to suppress. The Sockeye (2015) and Hastings (2011) fires had substantial suppression costs of approximately $\$ 8$ million and $\$ 18.5$ million, respectively. The 2019 fire season saw seven wildfires with estimated suppression costs greater than $\$ 10$ million, with the Swan Lake fire topping out at $\$ 43.6$ million. Previous research estimates that future Alaskan wildfire suppression costs will be over one billion dollars over the next 100 years [11]. While these costs are considered small compared to those in other parts of the United States, they are disproportionately large considering the population of the state.

Homeowners do not pursue sufficient wildfire risk mitigation activities [19]. Even though risk mitigation actions have been shown to be equal to or more cost effective than 
direct wildfire suppression actions, WUI homeowners tend to under mitigate [15]. Within the WUI, the range of land ownership, from public to private, makes pursuing wildfire risk mitigation actions more difficult. Recent research suggests neighborhoods that reduce fuels on property closer to public wildland boundaries slow the spread of wildfire through the neighborhoods better than evenly distributed neighborhood fuel reductions [20]. In this context, a buffer strategy is an arrangement of hazardous fuel reduction that prioritizes the contact boundary separating wildlands and homes in the WUI neighborhood. This neighborhood level risk reduction could have unintended consequences, as it could create incentives for homeowners further away from this contact boundary to be satisfied with indirect wildfire risk reductions provided by their neighbors without pursuing hazardous fuels reduction on their own properties. There is also a link between the risk reducing activities of homeowners living in WUI locations and the value of their homes [21].

Privacy and amenity values may discourage homeowner wildfire risk mitigation actions [22,23]. WUI residents may be reluctant to modify landscaping on their property until a wildfire is imminent [19]. Homeowners also display this reluctance with a lower WTP for risk mitigation activities on their own property when compared to risk mitigation activities on nearby public lands [13]. In one experimental setting, fuel treatments on nearby public lands produced a 'crowding out' effect as subjects responded to increased public risk mitigation activities by reducing spending on private risk mitigation actions. [24,25]. There is also a common thought that homeowner protection from wildfire will come from local, state or county/borough government suppression agencies. An analysis by Vogt et al. [26] found that trust in these governmental agencies to defend homeowner property from wildfire was significant. Additionally, the self-assessment of wildfire risk can predict homeowner behavior more than objective wildfire risk. Private homeowners can underestimate the objective risk levels in their community, as education programs were positively correlated with higher levels of homeowner fuel mitigation [27]. This increased risk information drove risk mitigation behavior more than previous wildfire experience [28]. Even while acknowledging that education increases risk mitigation activities, government programs have had inadequate financial support for education-based wildfire programs [29]. The advantage of decreasing wildfire risk by increasing mitigation activities is intuitive, but these reasons provide insight on why homeowners do not always maintain their fuel loads in WUI communities.

So, what drives homeowners to invest in fire mitigation activities on their properties? There is evidence that suggests social norms influence homeowners in WUI areas to participate in these activities [30]. Specifically, non-expert and informal information from other community members affects homeowner perceptions of wildfire risk. A 2013 study identified both a "sense of community" and "community problem solving" as motivators to increase mitigation actions on homeowner property [31]. Community engagement is also positively associated with involvement in community wildfire programs [32]. Even with adequate insurance, homeowners in WUI communities had large WTP for wildfire risk reduction through pre-suppression actions [24]. While homeowner's insurance can mitigate loss, it rarely covers all loses [33]. There are several studies using a wide range of methodologies and techniques that examining the non-market valuation of wildfire risk reduction [13,33,34]. Many of these studies show positive and significant WTPs across different wildfire risk areas and regions in the US, suggesting that we can attempt to identify WTP estimates for wildfire risk reduction in Alaska.

\section{Materials and Methods}

In the context of this work, Table 1 defines terms as we have used them in the text. 
Table 1. Terminology and definitions of key vocabulary used in the study.

\begin{tabular}{cc}
\hline Term & Definition \\
\hline Variable & Categories in the choice experiment that have different attribute levels. \\
Attribute level & Different options a variable can have in the choice experiment. \\
Utility & Value that one receives from a choice or action. \\
Risk & Probabilistic chance that a homeowner will encounter a hazard. \\
Hazard & An act that causes damage to a home or property (wildfire). \\
Non-Market & Services or benefits that are not directly sold in a market. \\
\hline
\end{tabular}

We used a discrete choice experiment, along with a prequestionnaire to assess homeowner willingness-to-pay for fuel treatment actions on their property. Discrete choice experiments are an important tool to assess nonmarket benefits by examining a type of stated preference valuation. While there are significant short comings with this methodology in a hypothetical setting [35], it is a significant improvement on previous methods of evaluating the nonmarket values of natural resources [36]. In a choice experiment, respondents are presented with choice sets that are comprised of combinations of variable attribute levels. Assuming that respondents will select the option that gives them the greatest utility, their choices can be used to estimate WTP for each of the variable attribute levels. The choice experiment asked homeowners to select their most preferred scenario from a set of three alternatives. Each option was comprised of five variables with different attribute levels (Table 2). The variables included the cost to the homeowner of reducing fuels on their property, the number of neighbors reducing fuels on their property, and the level of risk reduction to the homeowner and to their neighbors. Finally, scenarios also included land management agency decisions reflected by the type of fuel treatment pursued on nearby public lands. As seen in Figure 1, land management agency actions included 'none', thinned (removal of hazardous fuels from forest floor and understory) and cleared (near complete removal of all hazardous fuels). There are a number of variables that drive homeowner behavior, so it is vital to identify the most important indicators of this behavior and attempt to assess their utility. We vetted all variable levels through multiple pilot surveys to evaluate their feasibility in a field setting.
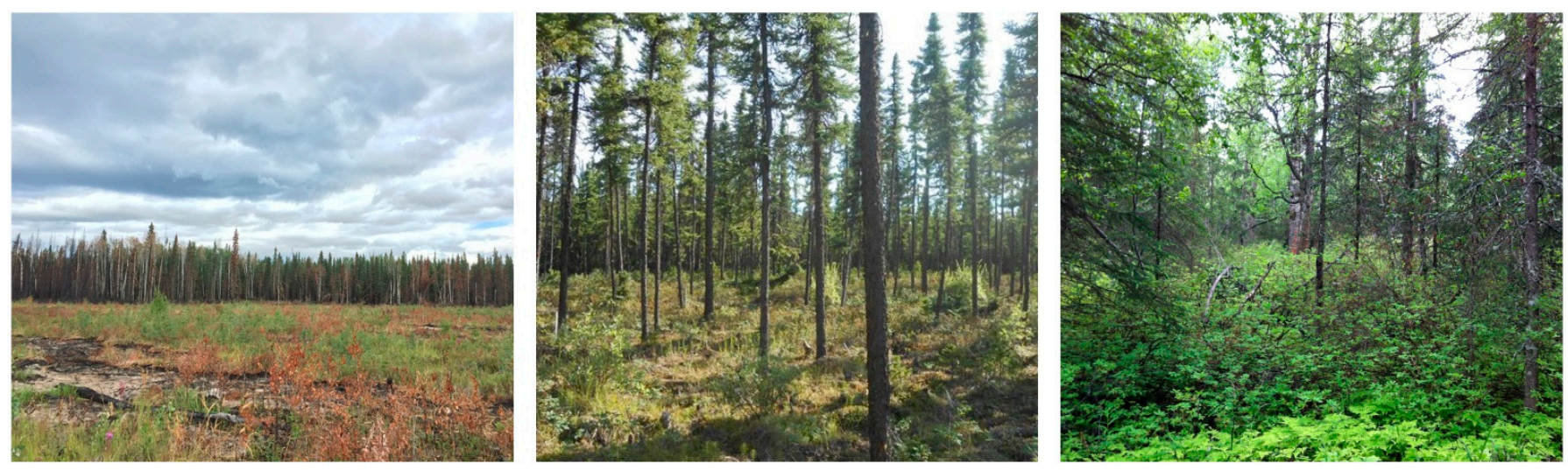

Figure 1. From left to right: Images that were included in the survey to describe the land management agency actions for fuel treatments as cleared, thinned and none. 
Table 2. Choice Experiment variables and corresponding attribute levels. The cost variable had five attribute levels from $\$ 0$ to $\$ 2000$. The other variables had three attribute levels

\begin{tabular}{|c|c|c|c|c|c|}
\hline Variable & $\begin{array}{c}\text { Cost of Preparing Your } \\
\text { Property }\end{array}$ & $\begin{array}{l}\text { Number of Nearby Neighbors } \\
\text { Preparing Their Property }\end{array}$ & $\begin{array}{l}\text { Fuel Treatment Type on } \\
\text { Neighboring Public Lands }\end{array}$ & $\begin{array}{c}\text { Reduction in Wildfire Risk to } \\
\text { Your Property }\end{array}$ & $\begin{array}{c}\text { Reduction in Wildfire Risk to } \\
\text { Your Neighbors }\end{array}$ \\
\hline Attribute level 1 & $\begin{array}{l}\text { No action on your } \\
\text { property }\end{array}$ & $\begin{array}{l}\text { No neighbors preparing their } \\
\text { property }\end{array}$ & $\begin{array}{l}\text { No fuel treatment on nearby } \\
\text { public lands }\end{array}$ & No reduction in wildfire risk & No reduction in wildfire risk \\
\hline Attribute level 3 & $\$ 1000$ & $\begin{array}{l}5 \text { or more neighbors preparing } \\
\text { their property }\end{array}$ & $\begin{array}{c}\text { Nearby public lands have cleared } \\
\text { fuel breaks where all trees have } \\
\text { been removed }\end{array}$ & $\begin{array}{c}50 \% \text { reduction in risk over } 10 \text { years } \\
\text { (from a } 20 / 1000 \text { chance to a } \\
10 / 1000 \text { chance) }\end{array}$ & $\begin{array}{c}50 \% \text { reduction in risk over } 10 \text { years } \\
\text { (from a } 20 / 1000 \text { chance to a } \\
10 / 1000 \text { chance) }\end{array}$ \\
\hline Attribute level 4 & $\$ 1500$ & none & none & none & none \\
\hline Attribute level 5 & $\$ 2000$ & none & none & none & none \\
\hline
\end{tabular}


We implemented the discrete choice experiment as an online survey, with a significant prequestionnaire. To be eligible for inclusion in the sample, a homeowner needed to live in an area with significant wildfire risk and needed to have current contact information in the local property tax database. Once we pooled the eligible homeowners into a sample frame, we randomly selected 1000 homeowners from two Alaskan boroughs: The Kenai Peninsula Borough and the Fairbanks-North Star Borough. Homeowners were initially contacted by letter and asked to participate in the survey. After follow-up contact, a total of 388 homeowners participated in the survey (with a response rate of $19.4 \%$ ). Each respondent viewed approximately six choice sets comprised of three scenarios each (average of 18 total choice scenarios) which were differentiated by randomly selected variable attributes levels. Respondents identified their most preferred option from each set of scenarios. The prequestionnaire allows us to use responses in the context of WTP. Specifically, we included open ended questions to elucidate reasoning behind respondent choices. The prequestionnaire spent significant time explaining various topics, definitions, and considerations to increase a respondent's understanding before answering questions. The technical methodology employed for estimating WTP from survey responses includes Random Utility Model (RUM) and Hierarchical Bayesian (HB) estimation [37,38]. A more thorough discussion of these topics, including choice experiment design can be found in Molina 2019 [39]. A copy of the survey instrument can be furnished upon request.

Our response rate allows us to make inferences at a confidence interval of $\pm 5 \%$ with a $95 \%$ confidence level for the entire state. While every effort was put into the random selection of homeowners for the survey, the distribution of respondent demographics did not match up to the demographic picture of the state. Specifically, survey respondents between the ages of 40-69 were overrepresented, as well as those with associates degrees or higher, and households with gross annual household income from $\$ 50,000-\$ 150,000$. Although our results aren't generalizable to the state, our sample does reflect that homeowners in the study regions are also more likely to have higher education, be older, and have more income than non-home owning Alaskans.

\section{Results}

Respondents who completed the choice experiment portion of the survey $(n=358)$ had a greater willingness-to-pay for treating fuels on their own property when one to four neighbors engaged in property mitigation than when no neighbors participated or when five or more neighbors mitigated fire hazard on nearby properties (Table 3). When neighboring land management agencies conducted hazardous fuel reduction actions, homeowners clearly preferred fuel thinning over clear-cutting fuels (least preferred) and taking no action. Private risk reduction spending increases with the level of wildfire risk reduction but does so at a diminishing rate. Responses to reducing the wildfire risk to neighbor's property followed the same trends. In summary, homeowners were most willing-to-pay for reducing fuels on their property when 1-4 neighbors also participated in fuel reduction actions, fuels were reduced on public lands by thinning, and the risk to themselves and the neighborhood was reduced by $50 \%$.

Table 3. Willingness-to-Pay (WTP) estimates for all choice experiment respondents. Baseline (least preferred) attribute levels are indicated by "-" WTP.

\begin{tabular}{cc}
\hline Variable Attribute Level & WTP \\
\hline Number of nearby neighbors preparing their property & - \\
No neighbors preparing their property & $\$ 319.24$ \\
$1-4$ neighbors preparing their property & $\$ 14.78$ \\
5 or more neighbors preparing their property & - \\
Fuel treatment type on neighboring public lands & \\
Cleared & $\$ 1456.56$ \\
\hline
\end{tabular}


Table 3. Cont.

\begin{tabular}{cc}
\hline Variable Attribute Level & WTP \\
\hline None & $\$ 764.58$ \\
Reduction in wildfire risk to your property & - \\
No reduction in wildfire risk & $\$ 1050.02$ \\
$25 \%$ reduction in risk over 10 years & $\$ 1179.36$ \\
$50 \%$ reduction in risk over 10 years & - \\
Reduction in wildfire risk to your neighbors & \\
No reduction in wildfire risk & $\$ 596.27$ \\
$25 \%$ reduction in risk over 10 years & $\$ 652.91$ \\
$50 \%$ reduction in risk over 10 years & \\
\hline
\end{tabular}

\section{Discussion}

The results are generally consistent with behaviors found in other studies [19]. Specifically, spending on private risk mitigation is tied to amenity values (privacy, shade, visual appeal, wind abatement etc.) and the social norms of contribution. While homeowners saw neighbor mitigation as beneficial, excessive amounts of this activity were less preferred, as shown in the smaller WTP estimates for five or more neighbors mitigating. This level of neighbor involvement may have been seen as removing too much vegetation in the neighborhood. Homeowners preferred certain actions irrespective of other considerations (cost, risk reduction, and land management agency mitigation), indicating that amenity values drove homeowner choices. On the other hand, since WTP estimates were similar for no neighbors mitigating and five or more neighbors mitigating, this middle ground suggests that there is a balance between preserving amenity value and contributing to the social good. Especially when we consider that respondents aren't willing to pay for wildfire risk reduction when at least a few neighbors aren't pursuing the same activity. These results suggest that surveyed homeowners wanted community level participation in fuel reduction but did not want to change vegetation within the landscape to the point of diminishing the aesthetic value of the neighborhood.

Land management decisions on public lands near WUI communities need to consider the amenity values fuel loads can provide. Previous studies indicate that both thinned and clear-cut fuel treatments reduce the severity and rate of spread of wildfire in modelling settings [40]. If based solely on wildfire risk reduction, we would expect the dominant attribute level choice to be clear-cutting, followed by thinning and finally no mitigation, although lack of forest canopy does not guarantee zero fire risk. Homeowners, however, had a clear preference for thinned fuel treatments over cleared fuel breaks. Likewise, they also preferred no treatments on public lands over cleared fire breaks. The positive WTP for no mitigation on public lands suggests that homeowners would rather pay for fuel treatments through actions on their own property than for clear-cutting on nearby public lands.

There are several factors that may influence Alaskan homeowners' preferences for fuel treatments. One factor may be the existence of permafrost soils. These soils are always frozen and must remain so in order to provide stability for structures built on top of them. When clear cutting reduces shading and thermal insulative properties of the forest floor, thawing can destabilize infrastructure and induce erosional crack and sinkholes (thermokarst) [41]. Homeowners can control the reduction of fuels on their own land, and therefore the thawing effects of that fuel reduction. Another explanation is that homeowners value the amenities provided by hazardous fuels more than the expected risk reduction from fuel removal. The larger WTP estimates for no mitigation actions taken on public lands over clear-cutting public lands also supports this view. Homeowners preferred the thinned fuel treatments that provide both amenity value and wildfire risk reduction. However, the higher WTP for thinned fuel treatments do not align with the increased costs of these treatments, which can reach $\$ 8000$ per acre in Alaska [42]. Some of these results align with a Holmes et al. study [13] where WTP was larger for thinned fuel treatments 
on public lands than for direct homeowner risk reduction. A similar finding was seen in a qualitative analysis from Paveglio et al. [23].

The WTP values on risk reduction are intuitive but highlight some key results. WTP was higher for increased risk reduction for both the homeowner's property, as well as neighbors' property. However, WTP was much larger for risk reduction to a respondent's own property than their neighbor's. This suggests that choices are still driven primarily from an individual utility maximization perspective. However, the WTP for neighbor risk reduction also indicates that there is some level of altruism associated with respondent choices. The small differences in WTP from the $25 \%$ to the 50\% levels suggest that there was only a marginal increase in value for that amount of increase and that the impact of more risk reduction diminishes. This marginal increase was seen in similar amounts for both risk reduction on the homeowner's property, as well as neighbors' property.

\section{Conclusions}

While it is intuitive that homeowners want to reduce the risk of wildfire damaging their property, it is important to estimate how they value this reduction considering increases in future projected wildfire frequency and severity and continuous fuel accumulation. Alaskan homeowners in areas with significant wildfire risk had positive WTP for neighborhood fuel reductions, as well as mechanical thinning of fuels on surrounding public lands. The drastic differences in WTP for private mitigation when thinning is present implies that the amenity values of wildlands were a significant driver of this type of fuel reduction. There is evidence that suggests homeowners preferred shaded (thinned) treatments in areas underlain by permafrost to avoid adverse consequences to infrastructure and hydrology [43] and quantitative evidence suggests shaded vegetation breaks may be appealing for other amenity values. The best way to leverage the WTP estimates from this study is to use them when planning and incentivizing fuel reductions, both on public and private lands. Land managing agencies can leverage the significant WTP for thinned fuel treatments through vying for several payment mechanisms, including taxes and user fees. Risk analyses, especially those under the most likely climate scenarios, should target areas with the highest wildfire risk, and fuel treatment plans should be well-publicized with community involvement encouraged to entice homeowners to mitigate on their own property. While this work laid a foundation for understanding the preferences and motivation of homeowners for fire fuel reduction practices, the research should be expanded into other areas of the state (for example, rural Alaska) and could include many other types of wildfire mitigation and preparation activities. The IPCC report makes it very clear that swift action needs to be taken to adapt to changes to boreal forest wildfire regimes [9]. The state of Alaska must continue to be prepared for climate change and its effects on wildfire in the state.

Author Contributions: Conceptualization, A.M., J.L., S.D., R.J. and J.L.; methodology, A.M. and J.L.; software, A.M.; validation, J.L.; formal analysis, A.M.; investigation, A.M.; resources, A.M. and J.L.; data curation, A.M. and J.L.; writing—original draft preparation, A.M.; writing—review and editing, A.M., J.L., S.D., R.J.; visualization, A.M.; supervision, A.M., J.L., S.D., R.J.; project administration, A.M., J.L., S.D., R.J.; funding acquisition, J.L. All authors have read and agreed to the published version of the manuscript.

Funding: This research was funded by the Joint Fire Science Program (project 14-5-01-27), the University of Alaska Fairbanks Resiliency and Adaptation Program (fellowship award) and the University of Alaska Fairbanks School of Management. The APC was paid for with personal funds from an author (J.L.).

Institutional Review Board Statement: All subjects gave their informed consent for inclusion before they participated in the study. The study was conducted in accordance with the Declaration of Helsinki, and theprotocol was approved by the Ethics Committee of the University of Alaska Fairbanks Institutional Review Board (Project\# 976057-8 with an initial approval on 7 August 2016). 
Informed Consent Statement: All participants in the survey agreed to the following statement before being allowed to respond to the survey: "Thank you for taking part in this research study about Alaskan wildfire risk. The goal of this study is to learn what fuel reduction actions you would take part in. This study also looks at factors that change how you and your neighbors take these actions. You are being asked to take part in this study because you live in the wildlife urban interface (WUI). Please read this form carefully. Please ask questions about the study before deciding to participate. In this survey, you will be asked about your previous wildfire experiences. You will also be asked how you maintain your property. Most of these questions will be multiple choice, with a few being open answer. There will also be a choice experiment where you can choose from different risk reducing activities. All data gathered will be confidential and will not be associated with any personal information. Your responses will be kept completely anonymous. The data from this survey will only be shared with research personnel. This survey will be helpful for future studies of fuel treatments and wildfire risk. The only cost to do this survey is your time. Data will only be shared in group form. Your participation is voluntary and you may stop at any time. If you finish the entire survey, you will be entered in a drawing for one of 20-\$50 Amazon gift cards. The drawing will take place on November 30th. Your responses will be kept separate from personal information collected. Personal information collected will only be used for the drawing. This survey depends on the property owners in your area. The benefits to doing this survey include gaining more information about wildfire risks. It also includes how others value reducing this risk. This study aims to be useful to all people who live in or close to the WUI. At the end of the project, a report of findings will be available to the public. There may also be other documents and public presentations available to the public. Answering questions in this study may also affect policy and decision making on multiple governmental levels. Confidentiality: Your answers will not be associated with your name. Your answers will only be shared in group form. We will code your answers with a number so they are confidential. Only your PIN will be connected with your name. We will get rid of paperwork and store all survey records, such as the document connecting your name to your PIN. I agree to take this survey. I do not agree to take this survey. If you have questions, you may contact Allen Molina at acmolina@alsaka.edu or 907-474-5534. Also, Joseph Little may be contacted about this research at jmlittle2@alaska.edu or 907-474-2711. The UAF Institutional Review Board (IRB) is a group that examines research projects involving people. This review is done to protect the rights and welfare of people involved the research. If you have questions or concerns about your rights as a research participant, you can contact the UAF Office of Research Integrity at 474-7800 (Fairbanks area) or 1-866-876-7800 (toll-free outside the Fairbanks area) or uaf-irb@alaska.edu".

Data Availability Statement: All datasets used and analyzed in this study are available from the corresponding author on reasonable request. Survey data will have all individual identifiers removed before submission to respect respondent confidentiality.

Acknowledgments: The authors would like to thank the Alaska Department of Natural Resources, the Alaska Fire Service, and the Alaska Interagency Coordination Center. Specifically, we would like to thank Marsha Henderson, Kathryn Pyne and Gabriella Branson for their assistance with data collection and compilation. They would also like to thank Nathanial Burke and Brock Lane for data cleaning and methodological discussion. Finally, they would also like to thank the anonymous reviewers for their significant contributions to the quality of this article.

Conflicts of Interest: The authors declare no conflict of interest.

\section{References}

1. Radeloff, V.C.; Helmers, D.P.; Kramer, H.A.; Mockrin, M.H.; Alexandre, P.M.; Bar-Massada, A.; Butsic, V.; Hawbaker, T.J.; Martinuzzi, S.; Syphard, A.D.; et al. Rapid growth of the US wildland-urban interface raises wildfire risk. Proc. Natl. Acad. Sci. USA 2018, 115, 3314-3319. [CrossRef]

2. Haggstrom, D.A. Managing Fire in the Urban Interface of Interior Alaska. In Proceedings of the 2nd International Wildland Fire Ecology and Fire Management Congress, Orlando, FL, USA, 19 November 2003; pp. 16-20.

3. Drury, S.A.; Grissom, P.J. Fire history and fire management implications in the Yukon Flats National Wildlife Refuge, interior Alaska. For. Ecol. Manag. 2008, 256, 304-312. [CrossRef]

4. Williams, A.P.; Abatzoglou, J.T.; Gershunov, A.; Guzman-Morales, J.; Bishop, D.A.; Balch, J.K.; Lettenmaier, D.P. Observed impacts of anthropogenic climate change on wildfire in California. Earth's Future 2019, 7, 892-910. [CrossRef]

5. Malevsky-Malevich, S.P.; Molkentin, E.K.; Nadyozhina, E.D.; Shklyarevich, O.B. An assessment of potential change in wildfire activity in the Russian boreal forest zone induced by climate warming during the twenty-first century. Clim. Chang. 2008, 86, 463-474. [CrossRef] 
6. Joly, K.; Duffy, P.A.; Rupp, T.S. Simulating the effects of climate change on fire regimes in Arctic biomes: Implications for caribou and moose habitat. Ecosphere 2012, 3, 1-18. [CrossRef]

7. Partain, J.L.; Alden, S.; Bhatt, U.S.; Bieniek, P.A.; Brettschneider, B.R.; Lader, R.T.; Olsson, P.Q.; Rupp, T.S.; Strader, H.; Thoman, R.L., Jr.; et al. 4. An assessment of the role of anthropogenic climate change in the alaska fire season of 2015. Bull. Am. Meteorol. Soc. 2016, 97, S14-S18. [CrossRef]

8. Woo, S.H.L.; Liu, J.C.; Yue, X.; Mickley, L.J.; Bell, M.L. Air pollution from wildfires and human health vulnerability in Alaskan communities under climate change. Environ. Res. Lett. 2020, 15, 094019. [CrossRef]

9. Jia, G.; Shevliakova, E.; Artaxo, P.; de Noblet-Ducoudré, N.; Houghton, R.; House, J.; Kitajima, K.; Lennard, C.; Popp, A.; Sirin, A.; et al. Land-climate interactions. In Climate Change and Land: An IPCC Special Report on Climate Change, Desertification, Land Degradation, Sustainable Land Management, Food Security, and Greenhouse Gas Fluxes in Terrestrial Ecosystems; Shukla, P.R., Skea, J., Buendia, E.C., Masson-Delmotte, V., Pörtner, H.-O., Roberts, D.C., Zhai, P., Slade, R., Connors, S., van Diemen, R., Eds.; IPCC: Geneva, Switzerland, 2019; pp. 131-247.

10. Westerling, A.L.; Bryant, B.P. Climate change and wildfire in California. Clim. Chang. 2008, 87, 231-249. [CrossRef]

11. Melvin, A.M.; Murray, J.; Boehlert, B.; Martinich, J.A.; Rennels, L.; Rupp, T.S. Estimating wildfire response costs in Alaska's changing climate. Clim. Chang. 2017, 141, 783-795. [CrossRef]

12. Hammer, R.B.; Stewart, S.I.; Radeloff, V.C. Radeloff Demographic trends, the wildland-urban interface, and wildfire management. Soc. Nat. Resour. 2009, 22, 777-782. [CrossRef]

13. Holmes, T.P.; Loomis, J.; González-Cabán, A. A mixed logit model of homeowner preferences for wildfire hazard reduction. In Proceedings of the Third International Symposium on Fire Economics, Planning, and Policy: Common Problems and Approaches, Albany, CA, USA, 2010; pp. 124-136. Available online: https://www.fs.usda.gov/treesearch/pubs/39093 (accessed on 10 October 2021).

14. Stein, S.M.; Menakis, J.; Carr, M.A.; Comas, S.J.; Stewart, S.I.; Cleveland, H.; Bramwell, L.; Radeloff, V.C. Wildfire, Wildlands, and People: Understanding and Preparing for Wildfire in the wildland-Urban Interface-a Forests on the Edge Report. In General Technical Report (GTR); Rocky Mountain Research Station, 2013; 36p. Available online: https: //www.semanticscholar.org/paper/Wildfire\%2C-wildlands\%2C-and-people\%3A-understanding-and-Stein-Menakis/722ed1 08a43e4b2f2353cb1bf239014fd699436e (accessed on 10 October 2021).

15. Jonathan, Y.; Lankoande, M. An Econometric Model of Wildfire Suppression Productivity; No. 2006-10; School of Economic Sciences, Washington State University: Pullman, WA, USA, 2006.

16. NFPA.Org. How to Prepare Your Home for Wildfires. 1 September 2020. Available online: https://www.nfpa.org//-/media/ Files / Firewise/Fact-sheets / FirewiseHowToPrepareYourHomeForWildfires.pdf (accessed on 10 October 2021).

17. Alaska Statewide Master Agreement. AICC_Alaska Statewide Master Agreement. 2019. Available online: https://fire.ak.blm. gov/administration/asma.php (accessed on 10 October 2021).

18. Bhatt, U.S.; Lader, R.T.; Walsh, J.E.; Bieniek, P.A.; Thoman, R.; Berman, M.; Borries-Strigle, C.; Bulock, K.; Chriest, J.; Hahn, M.; et al. Emerging Anthropogenic Influences on the Southcentral Alaska Temperature and Precipitation Extremes and Related Fires in 2019. Land 2021, 10, 82. [CrossRef]

19. Brenkert-Smith, H.; Champ, P.A.; Flores, N. Insights into wildfire mitigation decisions among wildland-urban interface residents. Soc. Nat. Resour. 2006, 19, 759-768. [CrossRef]

20. Butry, D.; Donovan, G. Protect thy neighbor: Investigating the spatial externalities of community wildfire hazard mitigation. For. Sci. 2008, 54, 417-428.

21. Collins, T.W. What influences hazard mitigation? Household decision making about wildfire risks in Arizona's White Mountains. Prof. Geogr. 2008, 60, 508-526. [CrossRef]

22. Kobayashi, M.; Zirogiannis, N.; Rollins, K.S.; Evans MD, R. Estimating Private Incentives for Wildfire Risk Mitigation: Determinants of Demands for Different Fire-Safe Actions. No. 320-2016-10198. 2010. Available online: https:/ / www.semanticscholar.org/paper/ Estimating-Private-Incentives-for-Wildfire-Risk-of-Kobayashi-Zirogiannis/e9eec875a1f7a606fec503e875cb294148aae050 (accessed on 10 October 2021).

23. Paveglio, T.B.; Abrams, J.; Ellison, A. Developing fire adapted communities: The importance of interactions among elements of local context. Soc. Nat. Resour. 2016, 29, 1246-1261. [CrossRef]

24. Talberth, J.; Berrens, R.P.; McKee, M.; Jones, M. Averting and insurance decisions in the wildland-urban interface: Implications of survey and experimental data for wildfire risk reduction policy. Contemp. Econ. Policy 2006, 24, 203-223. [CrossRef]

25. Prante, T.; Little, J.M.; Jones, M.L.; McKee, M.; Berrens, R.P. Inducing private wildfire risk mitigation: Experimental investigation of measures on adjacent public lands. J. For. Econ. 2011, 17, 415-431. [CrossRef]

26. Vogt, C.A.; Winter, G.; Fried, J.S. Predicting homeowners' approval of fuel management at the wildland-urban interface using the theory of reasoned action. Soc. Nat. Resour. 2005, 18, 337-354. [CrossRef]

27. Brenkert-Smith, H.; Champ, P.A.; Flores, N. Trying not to get burned: Understanding homeowners' wildfire risk-mitigation behaviors. Environ. Manag. 2012, 50, 1139-1151. [CrossRef] [PubMed]

28. Martin, W.E.; Martin, I.M.; Kent, B. The role of risk perceptions in the risk mitigation process: The case of wildfire in high risk communities. J. Environ. Manag. 2009, 91, 489-498. [CrossRef]

29. Reams, M.A.; Haines, T.K.; Renner, C.R.; Wascom, M.W.; Kingre, H. Goals, obstacles and effective strategies of wildfire mitigation programs in the wildland-urban interface. For. Policy Econ. 2005, 7, 818-826. [CrossRef] 
30. Brenkert-Smith, H.; Dickinson, K.L.; Champ, P.A.; Flores, N. Social amplification of wildfire risk: The role of social interactions and information sources. Risk Anal. 2013, 33, 800-817. [CrossRef] [PubMed]

31. Prior, T.; Eriksen, C. Wildfire preparedness, community cohesion and social-ecological systems. Glob. Environ. Chang. 2013, 23, 1575-1586. [CrossRef]

32. Agrawal, S.; Monroe, M.C. Using and improving social capital to increase community preparedness for wildfire. In The Public and Wildland Fire Management: Social Science Findings for Managers; US Department of Agriculture, Forest Service, Northern Research Station: Newtown Square, PA, USA, 2006; pp. 163-167.

33. Winter, G.J.; Fried, J.S. Estimating contingent values for protection from wildland fire using a two-stage decision framework. For Sci. 2001, 47, 349-360.

34. Loomis, J.B.; González-Cabán, A. Contingent valuation of fuel hazard reduction treatments. In The Economics of Forest Disturbances; Springer: Berlin/Heidelberg, Germany, 2008; pp. 229-243.

35. Rakotonarivo, O.S.; Schaafsma, M.; Hockley, N. A systematic review of the reliability and validity of discrete choice experiments in valuing non-market environmental goods. J. Environ. Manag. 2016, 183, 98-109. [CrossRef] [PubMed]

36. McFadden, D.; Train, K. (Eds.) Contingent Valuation of Environmental Goods: A Comprehensive Critique; Edward Elgar Publishing: Northhampton, MA, USA, 2017.

37. Walker, J.; Ben-Akiva, M. Generalized random utility model. Math. Soc. Sci. 2002, 43, 303-343. [CrossRef]

38. Sawtooth Software CBC/HB v5: Software for Hierarchical Bayes Estimation for CBC Data. 2016. Available online: https: //www.sawtoothsoftware.com/download/techpap/CBCHB_Manual.pdf (accessed on 10 October 2021).

39. Molina, A.C. Wildfire in Alaska: The Economic Role of Fuel Treatments and Homeowner Preferences in the Wildland Urban Interface. PhD Thesis, University of Alaska Fairbanks, Fairbanks, AK, USA, 2019.

40. Little, J.M.; Jandt, R.R.; Drury, S.; Molina, A.; Lane, B. Evaluating the Effectiveness of Fuel Treatments in Alaska-Final Report to the Joint Fire Science Program; University of Alaska Fairbanks: Fairbanks, AK, USA, 2018.

41. Pastick, N.J.; Jorgenson, M.T.; Wylie, B.K.; Nield, S.J.; Johnson, K.D.; Finley, A.O. Distribution of near-surface permafrost in Alaska: Estimates of present and future conditions. Remote Sens. Environ. 2015, 168, 301-315. [CrossRef]

42. St Clair, T.B. An Evaluation of Fuels Conversion Treatments in Interior Alaska. Master's Thesis, University of Alaska Fairbanks, Fairbanks, AK, USA, 2006.

43. Melvin, A.M.; Celis, G.; Johnstone, J.F.; McGuire, A.D.; Genet, H.; Schuur, E.A.; Rupp, T.S.; Mack, M.C. Fuel-reduction management alters plant composition, carbon and nitrogen pools, and soil thaw in Alaskan boreal forest. Ecol. Appl. 2018, 28, 149-161. [CrossRef] [PubMed] 